Piotr Fiedorczyk

Uniwersytet w Białymstoku e-mail: fiedorczyk@uwb.edu.pl

telefon: +48 857457153

DOI: $10.15290 /$ mhi.2015.14.01.08

\title{
Wizyta prawników radzieckich w Polsce w 1955 r. Dokument archiwalny o tematach i wynikach prawniczych konsultacji polsko-radzieckich
}

\begin{abstract}
SUMMARY
Soviet Lawyers' Visit to Poland 1955.

An Archive Document about Topics and Results of Polish-Soviet Legal Consultation

In 1955 the first official visit of Soviet lawyers to Poland took place. It is somehow strange that it took place so late, when the process of Sovietization of Polish law was already very advanced. The chairman of the delegation was Professor D. S. Kariew, who was also a high ranked official of the Soviet Ministry of Justice. The document presented below is the minutes of the last meeting of the delegation with Polish Minister of Justice, Henryk Świątkowski. The Soviet delegation was suggesting to implement many Soviet regulations into Polish law. Among them were: the election of judges (complete fiction) and abolishing the self-government of advocates. They were also pressing on increasing the Ministry's supervision over judges. At the time the Polish party seemed to accept these proposals but in the event none were implemented into Polish law. This was so because of political changes in Poland in 1956, when Stalin's period in Polish history ended. The process of reception of Soviet law in Poland then stopped, but not completely.
\end{abstract}

Key words: Soviet law, Soviet Ministry of Justice, Polish Ministry of Justice

Słowa kluczowe: prawo radzieckie, radzieckie Ministerstwo Sprawiedliwości, polskie Ministerstwo Sprawiedliwości

\section{Wprowadzenie}

W czasie trwającego w 1955 r. Miesiąca Pogłębiania Przyjaźni Polsko-Radzieckiej do Polski przybyła delegacja prawników radzieckich. Wizyta trwała od 27 września do 16 października, a delegacji przewodniczył Dimitrij Stiepanowicz Kariew - doktor nauk prawnych i profesor Uniwersytetu Moskiew- 
skiego im. Łomonosowa, dyrektor Departamentu Kodyfikacji i Systematyzacji Ustawodawstwa w Ministerstwie Sprawiedliwości ZSRR. W skład delegacji wchodzili ponadto: Ałła Władimirowna Bieldugina - naczelnik Wydziału Studiów i Popularyzacji Praktyki Sądowej w Ministerstwie Sprawiedliwości ZSRR oraz Nikołaj Spiridonowicz Ratnikow - zastępca naczelnika Wydziału Kadr w tymże Ministerstwie ${ }^{1}$. Trzytygodniowy pobyt był bardzo bogaty w spotkania. Miały one miejsce w Ministerstwie Sprawiedliwości, w Sądzie Najwyższym i sądach niższych instancji, w Prokuraturze Generalnej, na Wydziale Prawa i Administracji Uniwersytetu Warszawskiego ${ }^{2}$. W ramach spotkania z prawnikami działającymi w Zrzeszeniu Prawników Polskich 4 października prof. Kariew wygłosił odczyt Ustrój sądownictwa w ZSRR i przekazał polskim prawnikom pozdrowienia następującej treści: „Delegacja prawników radzieckich przebywająca w Warszawie w okresie dni Miesiąca Przyjaźni Polsko-Radzieckiej przekazuje prawnikom polskim serdeczne pozdrowienia od prawników ZSRR - prof. D. Kariew"3.

Była to pierwsza oficjalna wizyta prawników radzieckich w Polsce. Znamienne, że miała miejsce dopiero ponad dziesięć lat po powstaniu Polski Ludowej i dopiero w czasie, kiedy prawo Polski Ludowej zostało już w bardzo dużym stopniu zsowietyzowane. Relacje prasowe podkreślały entuzjastyczne powitania delegacji oraz przyjacielski i ciepły stosunek, jakim delegaci darzyli prawników polskich ${ }^{4}$. Stwierdzano, że pobyt delegacji stanowił „dalszy krok na drodze zacieśniania współpracy i wzajemnej pomocy pomiędzy prawnikami obu krajów" ${ }^{\prime \prime}$.

Propagandowy wymiar wizyty nie oznacza bynajmniej, iż w jej trakcie nie omawiano spraw ważnych. Prezentowany poniżej dokument jest protokołem podsumowującego wizytę spotkania z 15 października 1955 r., w którym oprócz delegacji radzieckiej - uczestniczyli najwyżsi rangą funkcjonariusze polskiego Ministerstwa Sprawiedliwości. Sporządzenie dokumentu było osobiście nadzorowane przez ministra sprawiedliwości Henryka Świątkowskiego, który naniósł nań odręczne poprawki. Protokół wysłano do wiadomości tow. Aleksandra Sława, który w Komitecie Centralnym PZPR sprawował wówczas funkcję zastępcy kierownika Wydziału Administracyjnego KC, nadzorującego resort sprawiedliwości ${ }^{6}$.

J. W., Prawnicy radzieccy z wizyta u prawników polskich, „Państwo i Prawo” 1955, nr 12, s. 1002.

2 Program pobytu delegacji prawników radzieckich, Archiwum Akt Nowych (dalej: AAN), zespół akt: Ministerstwo Sprawiedliwości (dalej: MS), sygn. 128, k. 48-49.

3 Z pobytu delegacji prawników radzieckich, "Nowe Prawo" 1955, nr 10, s. 98.

4 E. W., Wymiana doświadczeń z prawnikami Kraju Rad, „Biuletyn Ministerstwa Sprawiedliwości” 1955, nr 10 (numer specjalny), s. 2-9.

5 J. W., op. cit., s. 1003.

6 Towarzysz Aleksander Sław, ur. 1907, ps. Andrzej-drukarz, był członkiem KPP, PPR i PZPR. Funkcję zastępcy kierownika Wydziału Administracyjnego KC PZPR sprawował w latach 1955-1957, 
Dla kierownictwa polskiego Ministerstwa Sprawiedliwości szczególnie ważne były uwagi D. Kariewa. Na pierwszy plan wysunął on kwestię prac nad nową ustawą o ustroju sądów powszechnych, pozytywnie oceniając wysiłki Leszka Lernella, który koordynował te prace w Ministerstwie. Zagadnieniem trudnym do rozwiązania była konstytucyjna norma art. 50 ust. 1, który statuował zasadę wybieralności sędziów. Towarzysz Kariew doradzał, by wybór był dokonywany przez rady narodowe, przy udziale komitetów wojewódzkich PZPR. Nigdy tego nie zrealizowano, a sędziowie do końca PRL byli mianowani przez Radę Państwa ${ }^{7}$. Warto wspomnieć, że październikowa odwilż rychło obróciła wniwecz prace nad nową ustawą. Nieformalny wpływ PZPR na obsadę stanowisk sędziowskich miał jednak miejsce przez cały czas PRL.

Ciekawe są uwagi D. Kariewa o projekcie kodeksu karnego PRL. Prace nad nim były prowadzone niejawnie, a opublikowany w marcu 1956 r. tekst projektu został skrytykowany. Znamienne, że zarzuty zgłoszone przez Kariewa były wtedy też podnoszone ${ }^{8}$.

Gość skrytykował także istnienie samorządu adwokackiego i mającej pochodzić z wyborów Naczelnej Rady Adwokackiej. Stalinowska ustawa 27 czerwca 1950 r. prawo o ustroju adwokatury ${ }^{9}$ zachowywała jednak ograniczone formy samorządu adwokackiego. Jak wiadomo, Lenin z pogardą wyrażał się o adwokatach jako o „inteligenckiej hołocie”, którą trzeba ubrać w ,jeżowe rękawice". Rada prof. Kariewa, by zlikwidować NRA i zastąpić ją Ministerstwem Sprawiedliwości, bardzo pasowała do tego rozumowania.

D. Kariew sugerował także, aby w Ministerstwie utworzyć komórkę naukową na wzór radzieckiego Wszechzwiązkowego Instytutu Nauk Prawnych. Gość prawdopodobnie nie wiedział, że podobna instytucja w Polsce istniała. Była nią utworzona w 1949 r. Komisja Konsultacyjno-Naukowa przy Ministerstwie Sprawiedliwości, która odegrała ważną rolę w stalinizacji polskiej nauki i nauczania prawa. Została ona zlikwidowana w 1951 r., gdy w Ministerstwie przyjęto inne rozwiązania organizacyjne ${ }^{10}$.

Z kolei wypowiedź A. Bielduginy pokazuje, jak głęboko sięgały formy ministerialnego nadzoru nad sądami w ZSRR.

Protokół świetnie oddaje czołobitny stosunek polskiego kierownictwa resortu sprawiedliwości do towarzyszy radzieckich. Zastanawiające, że nie wi-

a następnie był w latach 1957-1960 sekretarzem Komisji ds. Narodowościowych KC PZPR. Dane podaję za internetowym Biuletynem Informacji Publicznej Instytutu Pamięci Narodowej.

7 A. Lityński, Historia prawa Polski Ludowej, wyd. 5, Warszawa 2013, s. 41.

8 D. Maksimiuk, Dyskusja nad projektem kodeksu karnego z 1956 r., "Miscellanea Historico-Iuridica” 2008, t. VI, s. 125-141.

9 Dz. U. Nr 30, poz. 275.

10 Kwestię tę przedstawiam w złożonym do druku artykule napisanym na podstawie referatu wygłoszonego na Zjeździe Katedr Historycznoprawnych we wrześniu 2014 r. w Krakowie. Ukazał się on w księdze jubileuszowej prof. Andrzeja Zięby (UJ). 
dać w nim ani śladu postalinowskiej odwilży. Świadczą o tym niezwykle ciepłe pozdrowienia dla ministra sprawiedliwości ZSRR Konstantina Pietrowicza Gorszenina, jednego ze współodpowiedzialnych za stalinowskie zbrodnie sądowe. Ciekawe, że żadna $\mathrm{z}$ radzieckich sugestii nie została wprowadzona w życie.

Warto nadmienić, że $\mathrm{w}$ krótkim okresie doszło do rewizyty polskich prawników. Jej przebieg przedstawiła w najnowszej literaturze A. Stawarska-Rippel ${ }^{11}$.

Poniższy tekst znajduje się w zasobie archiwalnym Archiwum Akt Nowych w Warszawie. Została zachowana oryginalna pisownia .

\section{DOKUMENT}

1955, listopad 9, Warszawa - protokół z posiedzenia Kolegium Ministerstwa Sprawiedliwości z udziałem delegacji prawników radzieckich

Protokół Kolegium Ministerstwa Sprawiedliwości PRL z udziałem delegacji Ministerstwa Sprawiedliwości Związku Radzieckiego w dniu 15 października 1955 roku. $^{\text {a }}$

W posiedzeniu Kolegium wzięli udział: Kierownik Wydziału Administracyjnego Komitetu Centralnego PZPR Tow. Szymański,

jego zastępca tow. Sław

i Instruktor KC PZPR Tow. Wieczorek.

Posiedzenie zagaił Minister Świątkowski, który prosił delegację radziecką o podzielenie się wrażeniami z pobytu w Polsce.

Pierwszy zabrał głos kierownik delegacji radzieckiej prof. D. S. Kariew:

W czasie naszego pobytu w Polsce staraliśmy się w miarę możności zaznajomić się z pracę i działalnością organów wymiaru sprawiedliwości PRL, przeprowadziliśmy szereg rozmów z pracownikami Ministerstwa Sprawiedliwości, Sądu Najwyższego i Generalnej Prokuratury. Nadto udało się nam przeprowadzić bezpośrednie rozmowy i zaznajomić się z działalnością organów wymiaru sprawiedliwości na miejscu, t. j. w sądach wojewódzkich i powiatowych.

Bardzo ważnym i ciekawym wydaje się nam zagadnienie ustroju sądów i opracowanie ustawy o ustroju sądów w PRL. Należy podkreślić, że tow.

\footnotetext{
11 A. Stawarska-Rippel, Resort sprawiedliwości ZSRR w świetle sprawozdania polskiej delegacji (1956), „Roczniki Administracji i Prawa” 2015, r. XIV, t. 1, s. 102-113.

a Z lewej strony ręcznie dopisane: „Tow. Dyr. Gab. Przejrzałem. Myślę, że z poprawkami może być przepisany na czysto. 5 XI" obok nieczytelny podpis ministra Henryka Świątkowskiego.
} 
Lernell i jego współpracownicy z głębokim namysłem, sumiennie, pracowali nad projektem wspomnianej ustawy.

Zaznajomiliśmy się z działalnością sądów wojewódzkich i powiatowych. Jeżeli chodzi o wybory sędziów powiatowych to wydaje się słuszne, żeby sędziów tych wybierały powiatowe rady narodowe a nie ludność w drodze wyborów powszechnych. Powiatowe rady narodowe nie zawsze będą miały należyte podejście do zagadnienia doboru sędziów i dlatego konieczne jest uprzednie zakwalifikowanie kandydatów na sędziów

przez komitety wojewódzkie partii. W Związku Radzieckim sędziowie ludowi /Wasi sędziowie powiatowi/ są w nomenklaturze obwodowych komitetów Partii. Należy zwracać uwagę na uświadomienie polityczne i ogólne wiadomości prawnicze kandydatów na sędziów. [Sędziowie w ZSRR należą do kategorii pracowników państwowych o nienormowanym czasie pracy] $]^{\mathrm{b}}$.

Jeżeli chodzi o wybór ławników to wydaje mi się, że byłoby to słusznym zorganizować tak, jak to było dawniej w Związku Radzieckim, że rady narodowe ustalały odpowiednią liczbę ławników w poszczególnych zakładach pracy, których załogi dokonują wyboru tych ławników. Specjalnie powołane komisje rad narodowych czuwałyby nad przeprowadzeniem tych wyborów. Należy wprowadzić zasadę, że kandydat na ławnika powinien uprzednio wyrazić swą zgodę na piśmie.

W ZSRR w województwach /obłastiach/ istnieją zarządy sprawiedliwości, które m.in. przeprowadzają prace przygotowawcze do wyborów. W Polsce utworzenie takich zarządów wydaje się niecelowe.

Co do części ogólnej projektu kodeksu karnego PRL wydaje mi się, że terminologia niektórych przepisów jest zbyt zawiła i mało zrozumiała dla ogółu. Ustawy należy pisać bardzo przejrzyście, żeby były one zrozumiałe dla wszystkich.

Jeżeli chodzi o projektowane sankcje, to uważam, że nie jest wskazane stawianie sądowi tak szerokich granic, jak np. od 2 do 15 lat. Należałoby te granice ścieśnić. Tak szerokie ramy sankcji mogłyby być odpowiednie tylko co do przestępstw wyjątkowych. Ustawodawca powinien sam rozstrzygać zagadnienie stopnia społecznego niebezpieczeństwa przestępstwa, a nie dopiero sąd w wyroku.

Szybkie przeprowadzenie wyborów do organów adwokatury - czego wymaga ustawa - uważałbym za konieczne. Co do adwokatury, to wydaje mi się, że mogłoby nie być Naczelnej Rady Adwokackiej. Wystarczyłyby wojewódzkie rady adwokackie i ich prezydia. Na zewnątrz przedstawicielem adwokatury mogłoby być Ministerstwo Sprawiedliwości, tym bardziej, że Naczelna

b Zdanie dopisane odręcznie. 
Rada Adwokacka składa się zasadniczo z adwokatów warszawskich. Aplikacja $\mathrm{w}$ adwokaturze wydaje się nam zbyt długa.

$$
-3-
$$

Bardzo dobrze, że Minister Sprawiedliwości ma prawo wnoszenia rewizji nadzwyczajnej. Wydaje się, że udzielone prezesowi Sądu Najwyższego prawo do wnoszenia rewizji nadzwyczajnej należałoby cofnąć. Stan taki stwarza warunki moralnego nacisku prezesa Sądu Najwyższego na sędziów tego Sądu. Praktyka w ZSRR wskazuje, że rewizje nadzwyczajne wnoszone przez Prokuratora Generalnego w dużym procencie nie są uwzględniane, podczas gdy rewizje nadzwyczajne wnoszone przez prezesa S[ądu] N[ajwyższego] z reguły są uwzględniane.

Prawo Ministra Sprawiedliwości do wnoszenia rewizji nadzwyczajnej wynika z jego funkcji nadzorczej nad sądami. Moim zdaniem praktyka Związku Radzieckiego powinna również pójść po tej linii.

Nie jest wskazane, żeby ci sami sędziowie, którzy rozstrzygają o wnoszeniu rewizji nadzwyczajnej brali udział $\mathrm{w}$ jej rozpoznawaniu - tym samym jakby przesądza się wynik sprawy.

Co do ustroju sądów chciałbym zaznaczyć, że wszystkie trzy ogniwa, tj. sądy powiatowe, wojewódzkie i Sąd Najwyższy powinny rozpoznawać sprawy w pierwszej instancji. Oczywiście o ile chodzi o sąd wojewódzki, a zwłaszcza o Sąd Najwyższy, to funkcje ich jako sądów pierwszej instancji powinny ograniczać się do spraw b. ważnych z punktu widzenia społeczno-politycznego.

Współpraca z prasą nie jest u nas zorganizowana. Formy tej współpracy przyjęte u Was uważam za prawidłowe i sądzę, że również u nas należy rozważyć wprowadzenie tego rodzaju współpracy.

Co do prokuratury należy zauważyć, że przeważającą ilość spraw prowadzi milicja, a nie prokuratury. Zdawałoby się bardziej celowe przekazać milicji sprawy drobniejsze, a sprawy ważniejsze - prokuraturom.

[Sądy ubezpieczeń społecznych powinny pozostać w jednolitym ustroju sądów, zgodnie z Waszą Konstytucją, przy czym sprawy rozpoznawane obecnie przez Trybunał Ubezpieczeń Społecznych należałoby przekazać Sądowi Najwyższemu $]^{c}$.

Zaznajomiliśmy się z pracą Wydziału Prawa Uniwersytetu Warszawskiego. Stwierdziliśmy, że w pracach tego Wydziału zostały

$$
-4-
$$

ujęte doświadczenia $\mathrm{z}$ radzieckich wyższych zakładów naukowych. Obecnie $\mathrm{w}$ ZSRR do instytutów prawnych będą przyjmowane osoby w wieku lat 21, mające za sobą dwa lata pracy praktycznej. Kierują na studia komitety partyjne.

c Zdanie dopisane odręcznie. 
W ZSRR istnieje przy Ministerstwie Sprawiedliwości resortowa komórka naukowa - „Wszechzwiązkowy Instytut Nauk Prawnych”, którego zadaniem jest badanie pewnych zagadnień, np. zagadnień dotyczących przestępczości, jej przyczyn i nasilenia, opracowanie wytycznych dotyczących zmiany obowiązującego ustawodawstwa itp. W Instytucie tym są zatrudnieni zarówno teoretycy z różnych dziedzin prawa, jak i praktycy, posiadający wielkie doświadczenie w pracy związanej z wymiarem sprawiedliwości. Przypuszczam, że i Was rząd może zwrócić się się do Ministerstwa Sprawiedliwości o przedstawienie pewnych danych statystycznych, danych co do tego jakie są przyczyny przestępstw pewnego rodzaju, czy daje się zauważyć wzrost, czy też spadek ilości pewnych przestępstw. Wobec braku takiego instytutu Ministerstwo nie byłoby w stanie odpowiedzieć na te pytania. Sądzę, że istniejący u Was Komitet Nauk Prawnych przy Polskiej Akademii Nauk nie jest przygotowany do takich badań, że jego zadania są inne, uważałbym za wskazane utworzenie przy Waszym Ministerstwie takiego resortowego instytutu naukowego.

Pobyt $\mathrm{u}$ Was, towarzysze dał nam bardzo wiele. Wszystko co pożyteczne będziemy starali się wykorzystać w ZSRR. Konieczne jest zapewnienie bardziej ścisłej więzi i współpracy między Ministerstwem Sprawiedliwości ZSRR i Ministerstwem Sprawiedliwości PRL. W przyszłości wielce korzystną byłaby wymiana delegacji specjalistów w liczbie 2-3 osób. Odjeżdżając do ZSRR wynosimy od Was wiele wiadomości, z którymi postaramy się zaznajomić naszych towarzyszy.

Głos zabrała towarzyszka A[ła] W[ładimirowna] Bieldiugina

Zaznajomiłam się z działalnością Departamentu Nadzoru Sądowego i sądów. Zauważyłam, że w zasadzie te same zagadnienia interesują naszych prawników i Waszych. Cały szereg przepisów, z którymi udało się

$$
-5-
$$

nam zaznajomić, zaproponujemy naszemu kierownictwu wykorzystać u nas.

Szczególnie interesuje nas zagadnienie sądów dla nieletnich i instytucja kuratorów. Np. narada kuratorów w Bytomiu wywarła na mnie duże wrażenie. Zrozumiałam, że instytucja kuratorów ma poważne znaczenie wychowawcze, gdyż polega ona na wciągnięciu szerokiego aktywu społecznego do zagadnienia resocjalizacji młodzieży popełniającej przestępstwa. Sądzę, że doświadczenie to możemy przenieść do ZSRR.

Również nowe formy wizytacji sądów dokonywanych przez referaty orzecznictwa sądów wojewódzkich u Was, jak np. żądanie sprawozdania od prezesa sądu powiatowego przed wizytacją oraz skonfrontowanie go z materiałami wydziału rewizyjnego sądu wojewódzkiego i wynikami przeprowadzonych następnie wizytacji - stanowią interesującą metodę pomocy sądom. Przedstawimy to naszemu kierownictwu.

Chciałabym się wypowiedzieć także odnośnie istniejącego w Ministerstwie Sprawiedliwości PRL Departamentu Organizacji i Statystyki Sądowej. Moim 
zdaniem istnienie takiego Departamentu jest niecelowe. W naszym Ministerstwie wszystkie sprawy organizacyjne rozdzielone są między poszczególne departamenty stosownie do zakresu ich zadań. Np. sprawy etatów należą do Departamentu Kadr, a sprawy tworzenia nowych sądów - do Departamentu Nadzoru Sądowego. Wydział Notariatu jest wydzielony jako samodzielny. Także wydzielona jest statystyka. Stawiam pod rozwagę Towarzyszy celowość istnienia tego Departamentu.

W organizacji Departamentu Nadzoru Sądowego należałoby wydzielić $\mathrm{w}$ osobne jednostki organizacyjne pracowników zajmujących się badaniem orzecznictwa i pracowników załatwiających sprawy rewizji nadzwyczajnych. Projekt rewizji powinien sporządzać ten, kto przeprowadzał wizytacje i w związku z tym wykrył uchybienie. Taka praktyka jest $\mathrm{u}$ nas.

W ZSRR termin od wniesienia odwołania do rozpoznania go przez sąd drugiej instancji wynosi dwa tygodnie. U was daleko dłużej. Wydawałoby się celowe terminy te skrócić. Sprawy dotyczące odwołań od orzeczeń sądów pierwszej instancji przygotowuje sąd ludowy dla

$$
-6-
$$

sądu drugiej instancji, któremu przesyła odwołanie wraz z aktami sprawy i oznaczeniem terminu posiedzenia $\mathrm{w}$ drugiej instancji. Byłoby pożądane przyśpieszenie rozpoznawania spraw w Sądzie Najwyższym PRL. Jak zorientowałam się w Sądzie Najwyższym sprawy cywilne leżą do półtora roku, co moim zdaniem jest niedopuszczalne i uważam że można mieć pretensje do Sądu Najwyższego z tego powodu. Ten stan rzeczy należy bezwzględnie zmienić.

Należałoby również zwrócić uwagę na sposób redagowania orzeczeń Sądu Najwyższego. Powinny one być zredagowane [znacznie krócej i tak] d żeby były zrozumiałe dla wszystkich obywateli, a nie tylko dla prawników.

Towarzyszka Bieldiugina [dziękuje] $]^{\mathrm{e}}$ za serdeczne spotkania i rozmowy z pracownikami wymiaru sprawiedliwości PRL.

Nastepnie zabrał głos towarzysz Ratnikow:

Rozmawiałem wiele z pracownikami Departamentu Kadr i pracownikami sądów. Mogę z tego wyciągnąć jeden wniosek, że praca z kadrami w ZSRR i PRL w dziedzinie sprawiedliwości jest prowadzona na jednakowych podstawach. Zauważyłem, że w sądach polskich ma miejsce również połączenie bardziej doświadczonych sędziów z młodymi sędziami. Jest to linia słuszna. Należy systematycznie, $\mathrm{w}$ celu uniknięcia przewlekłości w pracy pracowników sądowych, podnosić ich poziom wyrobienia politycznego. Pracownicy Departamentu Kadr Ministerstwa Sprawiedliwości PRL pracują intensywnie w tym kierunku. W ZSRR tworzy się kursy doskonalenia kadr prawniczych. Takie poczynania są i u Was. Poczynania te należy rozwijać.

d Słowa dopisane odręcznie.

e Słowo nadpisano. 
Uwagę moją zwróciły zdania o przeciążeniu sędziów w PRL. Sądzę, że to zagadnienie wymaga starannego rozważenia.

Podobał mi się system aplikacji młodych prawników. Zakomunikujemy to naszemu kierownictwu. Jednak sądzę, że okres aplikacji przewidziany w projekcie ustawy o ustroju sądów jest u Was nieco zbyt długi i możnaby go skrócić.

Wydział Obrotu Prawnego z Zagranicą istniejący w Ministerstwie Sprawiedliwości PRL odgrywa znaczną rolę w wymianie doświadczeń. My nie mamy podobnej komórki i przedstawimy to kierownictwu Ministerstwa Sprawiedliwości ZSRR w celu rozważenia sprawy utworzenia$$
-7-
$$

podobnego Wydziału.

Tow. [Nikołaj Spiridonowicz] Ratnikow dziękuje serdecznie za spotkania i rozmowy z pracownikami wymiaru sprawiedliwości w PRL.

Towarzysz Kariew zauważa, że w swoim czasie Sąd Najwyższy RFSRR także był przeciążony i w celu zlikwidowania takiego stanu rzeczy utworzono komisję, która m.in. postanowiła, że należy zwiększyć ilość etatów w Sądzie Najwyższym. Pozatym odciążenie Sądu Najwyższego nastąpiło przez wydanie dekretu o przekazaniu prezydiom sądów obwodowych rozpoznawanie niektórych rewizji nadzwyczajnych.

Towarzysz Minister Świątkowski - sądzę, że wszyscy zgodzą się ze mną, jeżeli powiem, że obecna tu delegacja prawników radzieckich przez czas pobytu [u nas poświęciła bardzo wiele trudu, by zaspokoić nasze gorące pragnienia poznania organizacji, metod pracy sądów oraz ustawodawstwa sądowego ZSRR. Wypowiedziane przez towarzyszy radzieckich poglądy i uwagi, bogate doświadczenia sądownictwa ZSRR są dla nas bardzo cenne] $]^{\mathrm{f}}$. Myślę, że nasze spotkanie jest szczególnie udane, praca intensywna $\mathrm{z}$ nami trwała prawie trzy tygodnie. [W pracach naszych wykorzystamy wiele waszych uwag dla dobra wymiaru sprawiedliwości Polski Ludowej]g.

Pozwalam sobie w imieniu wszystkich nas wyrazić tow. Kariewowi i członkom delegacji radzieckiej głęboką wdzięczność.

Proszę was Towarzysze, odemnie osobiście i od nas wszystkich przekazać tow. Ministrowi Gorszeninowi serdeczne pozdrowienia. Mam nadzieję, że stosunki nasze będą się zacieśniać coraz więcej we wszystkich kierunkach naszej działalności.

Wy, Towarzysze, jesteście pierwszą radziecką delegacją prawników w Polsce. Posłaliśmy już do Was dwie delegacje, mam nadzieję, że w przyszłości nastąpi stała wymiana delegacji prawników.

f Fragment dopisany odręcznie.

g Zdanie dopisane odręcznie. 
[Prosimy Was również o przekazanie naszych ${ }^{\mathrm{h}}$ serdecznych pozdrowień pracownikom Ministerstwa Sprawiedliwości ZSRR, Sądowi Najwyższemu ZSRR i wszystkim pracownikom wymiaru sprawiedliwości ZSRR.

$$
-8-
$$

Towarzysz Kariew: dziękuję wszystkim za przyjacielskie, serdeczne przyjęcie i zapewniam, że więź łącząca nas będzie się zacieśniać i w przyszłości odbywać się będzie stała wymiana naszych prawników, a zatem i stała wymiana doświadczeń.

Za zgodność

(podpis nieczytelny)

Ministerstwo Sprawiedliwości $\quad$ /Kruzel/i

Oryginał, mps z odręcznymi poprawkami H. Świątkowskiego

AAN zespół akt: Ministerstwo Sprawiedliwości 2266, k. 57-64.

\section{Bibliografia}

\section{Źródła archiwalne}

Program pobytu delegacji prawników radzieckich. Archiwum Akt Nowych (dalej: AAN), zespół akt: Ministerstwo Sprawiedliwości (dalej: MS), sygn. 128, k. 48-49.

Protokót Kolegium Ministerstwa Sprawiedliwości PRL z udziałem delegacji Ministerstwa Sprawiedliwości Zwiazku Radzieckiego w dniu 15 października 1955 roku. AAN, MS 2266, k. 57-64.

\section{Opracowania}

E. W., Wymiana doświadczeń z prawnikami Kraju Rad, „Biuletyn Ministerstwa Sprawiedliwości" 1955, nr 10 (numer specjalny).

J. W., Prawnicy radzieccy z wizyta u prawników polskich, „Państwo i Prawo” 1955, nr 12.

A. Lityński, Historia prawa Polski Ludowej, wyd. 5, Warszawa 2013.

D. Maksimiuk, Dyskusja nad projektem kodeksu karnego z 1956 r., „Miscellanea Historico-Iuridica" 2008, t. VI.

A. Stawarska-Rippel, Resort sprawiedliwości ZSRR w świetle sprawozdania polskiej delegacji (1956), „Roczniki Administracji i Prawa” 2015, t. XIV.

Z pobytu delegacji prawników radzieckich, „Nowe Prawo” 1955, nr 10.

h Fragment zdania dopisany odręcznie.

i Z lewej strony ręczna adnotacja: „Za zgodność”, nieczytelny podpis i pieczęć „Ministerstwo Sprawiedliwości". 